DOI.

https://doi.org/10.22219/fths.v3i2

Received: April 2020

Accepted: Mei 2020

Available online: Juli 2020

\title{
Karakter Fisikokimia Agar-Agar dari Rumput Laut Gracilaria sp. dengan Variasi Air Kelapa dan Lama Ekstraksi
}

\author{
Shandra Berliana ${ }^{1}$, Noor Harini ${ }^{*}$, Rista Anggriani ${ }^{1}$ \\ ${ }^{1}$ Program Studi Teknologi Pangan, Fakultas Pertanian Peternakan, Universitas Muhammadiyah \\ Malang, Malang, Indonesia \\ *Corresponding author email: harini@umm.ac.id
}

\begin{abstract}
Agar is a complex polysaccharide hydrocolloid that can be obtained from seaweed from the family Gracilaria sp. The function of agar is for gelling agent, thickener, stabilizer. In this research the extraction of agar from seaweed Gracilaria sp. used coconut water is able to reduce sulfate in seaweed, so can improve the properties of gel flour agar. This research was conducted in two stages. The first stage uses a factorial randomized block design consisting of 2 factors with 3 repetitions. The first factor was the ratio of seaweed and the ratio of coconut water $(1: 25 ; 1: 30 ; 1: 35)$. The second factor was extraction time (60 minutes, 90 minutes, 120 minutes). The agar extraction results were analyzed for yield, moisture content, ash content, viscosity, and gel strength. The second stage of the study was the application of agar flour to tomato fruit leather used a Simple Randomized Design model with various concentration of agar $(0.6 \%, 0.9 \%)$ compared to commercial agar $(0.6 \%, 0.9 \%)$. The parameters analyzed were water content, thickness, tensile strength, $p H$, total dissolved solids, color intensity, and organoleptic (taste, appearance, elasticity, preference). The results showed that there was a significant influence on the ratio of seaweed and coconut water and the extraction time, the agar produced to yield, water content, ash content, viscosity, and gel strength. The best treatment of agar that based on the SNI approach was in the R3T3 treatment, (seaweed: coconut water ratio of 1:35 with extraction time of 120 minutes) with a yield of $32.27 \%$, moisture content of $11.08 \%$, ash content of $3.75 \%$, strength gel $235.51 \mathrm{gr} / \mathrm{cm} 2$, viscosity $24.09 \mathrm{cP}$. The second stage of the study, the best results was obtained by adding agar to $0.9 \%$ with a moisture content of $8.13 \%$, total dissolved solids $23.79^{\circ}$ Brix, pH 4.03, thickness $0.39 \mathrm{~mm}$, tark strength $1.64 \mathrm{~N} / \mathrm{mm}^{2}$, color intensity $(L) 40.24,(a+) 22.92,(b+)$ 8.09, taste 5.9 (tasty), elasticity 5.65 (easy to roll), appearance 5,75 (interesting), like 5.4 (like).
\end{abstract}

Keywords: coconut water, flour agar, seaweed, time extraction

\section{PENDAHULUAN}

Sifat fisiko kimia agar-agar merupakan salah satu indikator yang menentukan kualitas agar-agar itu sendiri. Salah satu cara untuk menghasilkan kualitas agar-agar yang baik dengan memberikan perlakuan yang terbaik. Proses ekstraksi yang biasa dilakukan sering menggunakan bahan kimia yang cukup berbahaya untuk meningkatkan kekuatan gel pada agar-agar.

Berdasarkan permasalahan tersebut maka peneliti menggunakan metode alternatif ramah lingkungan dalam ekstraksi agar-agar seperti, penggunakan 
larutan organik (air kelapa) untuk pengganti larutan alkali sebagai bahan ekstraksi. Pada penelitian sebelumnya, Castaneda (2018) mengekstraksi karagenan dari rumput laut Gracilaria sp dengan air kelapa yang berpengaruh terhadap rendemen, kekuatan gel dan viskositas. Rahmat (2002) menyatakan bahwa pengaruh penambahan air kelapa sebagai pengganti $\mathrm{NaOH}$ pada proses ekstraksi dalam pembuatan agar-agar kertas penggunaan air kelapa 250\% sampai 300\% mampu menggantikan peranan $\mathrm{NaOH}$ dari segi kekuatan gel.

Kualitas agar-agar tidak hanya ditentukan oleh jenis pelarut yang digunakan namun juga lama waktu ekstraksi juga mejadi hal penting yang perlu diperhatikan karena mempengaruhi kualitas dari agar-agar yang dihasilkan. Castaneda (2018) menyatakan bahwa waktu ekstraksi 120 menit menghasilkan karakter karegenan dengan dengan nilai rendemen $42 \%$, kekuatan gel $428,99 \mathrm{~g} / \mathrm{cm} 2$, dan viskositas 5,11 cP. Oleh karena itu peneliti ingin menemukan rasio yang tepat antara rumput laut dan rumput laut Gracilaria sp serta waktu yang maksimal dalam proses ekstrasi agar-agar.

\section{METODE PENELITIAN}

\section{Bahan}

Bahan-bahan yang digunakan dalam pembuatan agar-agar meliputi rumput laut kering jenis Gracilaria sp. yang dipanen dari tambak Kraton Pasuruan, Jawa Timur, umur panen 45 hari, air kelapa tua yang diperoleh dari Pasar Besar Batu, Malang, Jawa Timur.

Alat

Alat yang digunakan pada penelitian ini adalah Cabinet Dryer, spektrofotometer, color reader, Tekxture Analyzer tipe EZ-SX, micrometer, dan pH metertipe Lab 875 (SI Analytics).

\section{Pembuatan Agar-Agar dari rumput laut Gracilaria sp}

Rumput laut Gracilaria sp. dicuci dari kotoran yang menempel, ditimbang 50 g yang telah kering $5 \mathrm{~cm}$, direndam dengan larutan $\mathrm{CaOCl}_{2} \quad 0,25 \%$ dalam $1000 \mathrm{~mL}$ selama $1 \mathrm{jam}$, kemudian rumput laut dicuci dengan air mengalir sampai air tidak berwarna, rumput laut dimasak dengan perbedaan variasi rasio rumput laut:air kelapa (1:25, 1:30, 1:35) dengan suhu $85^{\circ} \mathrm{C}$ sampai $95^{\circ} \mathrm{C}$ dan variasi lama waktu ekstraksi (60 menit, 90 menit, 120 menit). Aquades ditambahkan pada sampel dan dihancurkan selama 30 detik sampai homogen. Tambahkan asam asetat hingga $\mathrm{pH}$ menjadi 6 dengan suhu $90^{\circ} \mathrm{C}$ sampai $95^{\circ} \mathrm{C}$ selama 2 jam. Sampel disaring hingga menghasilkan filtrat kemudian dibiarkan filtratnya sampai membentuk gel selama 18 jam pada suhu ruang. Gel dikeringkan pada kabinet dryer pada suhu $45^{\circ} \mathrm{C}$ sampai $55^{\circ} \mathrm{C}$ selama 24 jam. Lembar agar-agar dihaluskan menggunakan blender hingga halus. 


\section{Parameter Penelitian}

Parameter yang diamati pada agar-agar rumput laut Gracilaria sp. adalah rendemen, kadar abu, kadar air, viskositas, kekuatan gel. Kemudian dilakukan penentuan perlakuan terbaik berdasarkan perbandingan dengan SNI agar-agar.

\section{Rancangan Percobaan dan Analisa Data}

Ekstraksi agar-agar dari rumput laut Gracilaria sp. menggunakan Rancangan Acak Kelompok (RAK) yang disusun secara faktorial dengan faktor pertama yaitu rasio rumput laut:air kelapa (1:25, 1:30, 1:35) dan faktor kedua adalah lama waktu ekstraksi (60 menit, 90 menit, 120 menit).

Pengolahan data pada penelitian ini menggunakan analisis ragam ANOVA (Analysis of Variance) untuk mengetahui pengaruh dari perlakuan. Apabila hasil analisa berpengaruh nyata atau interaksi pada masing-masing perlakuan, maka data yang sudah diperoleh akan dilanjutkan dengan uji pembeda dengan menggunakan uji DMRT (Duncan's Multiple Range Test) pada taraf 5\%. Penentuan untuk perlakuan terbaik akan dibandingkan dengan perlakuan penambahan agar-agar komersil yang ada dipasaran.

\section{HASIL DAN PEMBAHASAN}

\section{Karakteristik Fisik Agar-Agar dari rumput laut Gracilaria sp} Rendemen

Penambahan konsentrasi air kelapa dan lama waktu ekstraksi berpengaruh sangat nyata terhadap nilai rendemen agar-agar rumput laut yang dihasilkan. Pemilihan air kelapa dapat menggantikan larutan alkali seperti $\mathrm{NaOH}$ sebagai bahan ekstraksi dengan tujuan untuk mengurangi jumlah sulfat dan dapat meningkatkan kekuatan gel (Angka dan Maggy, 2000). Rendemen agar-agar akan bertambah seiring bertambahnya konsentrasi air kelapa yang digunakan. Hal ini dikarenakan dengan adanya sifat asam pada air kelapa yang mampu memecah dinding sel rumput laut sehingga agar-agar yang terekstraksi semakin banyak. Hal ini sesuai dengan Anggraini (2010) yang menyatakan bahwa sifat asam air kelapa mempu menghidrolisis dinding sel rumput laut yang tersusun atas polisakarida sehingga dapat meningkatkan rendemen agaragar. Proses hidrolisis ini menyebabkan dinding sel rumput laut semakin permeable dan lunak sehingga difusi dan ekstraksi agar-agar semakin mudah. Permeabilitas yang tinggi pada dinding sel ini akan meningkatkan rendemen agar-agar karena komponen yang ada dalam dinding rumput laut lebih mudah terekstraksi. 
Tabel 1. Rerata Rendemen Agar-agar Rumput Laut (\%) Akibat Perbedaan Penambahan Rasio Air Kelapa dan Lama Waktu Ekstraksi

\begin{tabular}{lccc}
\hline \multicolumn{1}{c}{ Perlakuan } & $\begin{array}{c}\text { Rendemen } \\
(\%)\end{array}$ & $\begin{array}{c}\text { Kekuatan } \\
\mathrm{Gel}\left(\mathrm{g} / \mathrm{cm}^{2}\right)\end{array}$ & $\begin{array}{c}\text { Viskositas } \\
(\mathrm{cP})\end{array}$ \\
\hline 1:25 waktu ekstraksi 60 menit & $28,38 \mathrm{a}$ & $231,58 \mathrm{a}$ & $21,97 \mathrm{c}$ \\
1:25 waktu ekstraksi 90 menit & $28,90 \mathrm{~b}$ & $231,94 \mathrm{~b}$ & $21,68 \mathrm{~b}$ \\
1:25 waktu ekstraksi 120 menit & $29,36 \mathrm{c}$ & $232,47 \mathrm{c}$ & $21,26 \mathrm{a}$ \\
1:30 waktu ekstraksi 60 menit & $29,91 \mathrm{~d}$ & $232,85 \mathrm{~d}$ & $23,82 \mathrm{f}$ \\
1:30 waktu ekstraksi 90 menit & $30,41 \mathrm{e}$ & $233,43 \mathrm{e}$ & $23,58 \mathrm{e}$ \\
1:30 waktu ekstraksi 120 menit & $30,70 \mathrm{ef}$ & $233,90 \mathrm{f}$ & $23,15 \mathrm{~d}$ \\
1:35 waktu ekstraksi 60 menit & $31,34 \mathrm{f}$ & $234,44 \mathrm{~g}$ & $24,89 \mathrm{i}$ \\
1:35 waktu ekstraksi 90 menit & $31,85 \mathrm{~g}$ & $234,92 \mathrm{~h}$ & $24,57 \mathrm{~h}$ \\
1:35 waktu ekstraksi 120 menit & $32,27 \mathrm{i}$ & $235,51 \mathrm{i}$ & $24,09 \mathrm{~g}$ \\
\hline
\end{tabular}

Angka-angka yang diikuti huruf yang sama menunjukkan tidak berbeda nyata pada Uji Duncan $\mathrm{a}=5 \%$

Meningkatnya rendemen agar-agar rumput laut juga dipengaruhi oleh lama waktu ekstraksi. Semakin lama waktu ekstraksi yang digunakan maka semakin banyak rendemen yang dihasilkan, karena semakin lama waktu ekstraksi maka kontak antara dinding rumput laut dan air kelapa semakin lama. Hal ini sesuai dengan Muchlisah (2012) yang menyatakan bahwa semakin lama waktu ekstraksi maka proses permeabilitas dinding sel semakin maksimal.

\section{Kekuatan Gel}

Penambahan konsentrasi air kelapa dan lama waktu ekstraksi berpengaruh sangat nyata terhadap nilai rendemen agar-agar rumput laut yang dihasilkan. Semakin banyak air kelapa yang ditambahkan maka semakin tinggi pula nilai kekuatan gel agar-agar, begitu juga sebaliknya. Adanya unsur kalium yang terdapat pada air kelapa sangat mempengaruhi nilai kekuatan gel pada agar-agar. Kalium ialah mineral utama yang terkandung dalam air kelapa (Santoso, 2003). Proses pembentukan gel terjadi karena adanya unsur kalium yang dapat mengikat rantai polimer dengan memperkuat struktur tiga dimensi sehingga polimer akan mempertahankan bentuknya jika terkena tekanan (Karyadi, 2002).

Peningkatan nilai kekuatan gel pada agar-agar juga dipengaruhi oleh lama waktu ekstraksi. Semakin lama waktu ekstraksi yang digunakan maka nilai kekuatan gel yang dihasilkan semakin tinggi. Hal ini dikarenakan semakin lama waktu ekstraksi yang digunakan maka kandungan sulfat lebih banyak menurun. Hal ini sesuai dengan Ega (2016) yang menyatakan bahwa rendahnya nilai kekuatan gel dipengaruhi oleh waktu ekstraksi dan tingginya sulfat. 


\section{Viskositas}

Nilai viskositas meningkat seiring bertambahnya konsentrasi air kelapa. Hal ini menunjukkan bahwa perlakuan penambahan jumlah air kelapa berpengaruh terhadap nilai viskositas. Nilai viskositas berbanding lurus dengan kekuatan gel agar-agar. Adanya unsur kalium dalam air kelapa menyababkan kekuatan gel dan nilai viskositas meningkat. Moirano (1977) yang menyatakan bahwa gaya tolak menolak antara ester sulfat di sepanjang rantai polimer menyebabkan molekul tertarik sehingga mengikat molekul air yang mengakibatkan viskositas agar-agar meningkat.

Lama waktu ekstraksi juga berpengaruh terhadap nilai viskositas pada agaragar. Semakin lama waktu ekstraksi yang digunakan maka akan semakin rendah nilai viskositas. Hal ini dikarenakan nilai viskositas berbanding lurus dengan kadar sulfat yang terkandung, dimana semakin lama waktu ekstraksi maka semakin rendah kadar sulfat agar-agar, sehingga nilai viskositas juga menurun.

\section{Karakteristik Kimia Agar-Agar dari rumput laut Gracilaria sp Kadar Air}

Semakin banyak air kelapa yang ditambahkan maka semakin rendah nilai kadar air agar-agar. Hal ini dikarenakan oleh penggunaan pelarut pengekstraksi pada penelitian kali ini menggunakan pelarut yang bersifat asam. Ekstraksi agar-agar pada umumnya menggunakan pelarut bersifat asam kuat yang mampu memberikan pengaruh terhadap nilai kadar air. Sesuai dengan Anwar (2003) yang menyatakan bahwa penurunan kadar air diakibatkan adanya pelarut yang bersifat asam seperti larutan air kelapa yang dapat menghambat terjadinya suatu peningkatan kadar air.

Tabel 2. Rerata Kadar Air Agar-agar Rumput Laut (\%) Akibat Perbedaan Penambahan Rasio Air Kelapa dan Lama Waktu Ekstraksi

\begin{tabular}{lcc}
\hline \multicolumn{1}{c}{ Perlakuan } & Kadar Air (\%) & Kadar Abu (\%) \\
\hline 1:25 waktu ekstraksi 60 menit & $15,32 \mathrm{f}$ & $2,38 \mathrm{~b}$ \\
1:25 waktu ekstraksi 90 menit & $14,90 \mathrm{ef}$ & $2,21 \mathrm{ab}$ \\
1:25 waktu ekstraksi 120 menit & $14,76 \mathrm{e}$ & $2,15 \mathrm{a}$ \\
1:30 waktu ekstraksi 60 menit & $13,13 \mathrm{~d}$ & $2,94 \mathrm{~d}$ \\
1:30 waktu ekstraksi 90 menit & $13,01 \mathrm{~cd}$ & $2,81 \mathrm{~cd}$ \\
1:30 waktu ekstraksi 120 menit & $12,89 \mathrm{c}$ & $2,70 \mathrm{c}$ \\
1:35 waktu ekstraksi 60 menit & $11,30 \mathrm{~b}$ & $3,90 \mathrm{~g}$ \\
1:35 waktu ekstraksi 90 menit & $11,13 \mathrm{ab}$ & $3,78 \mathrm{ef}$ \\
1:35 waktu ekstraksi 120 menit & $11,08 \mathrm{a}$ & $3,75 \mathrm{de}$ \\
\hline
\end{tabular}

Angka-angka yang diikuti huruf yang sama menunjukkan tidak berbeda nyata pada Uji Duncan $\mathrm{a}=5 \%$ 
Menurunnya nilai kadar air pada agar-agar juga dipengaruhi oleh lama waktu ekstraksi. Semakin lama waktu ekstraksi yang digunakan maka semakin rendah nilai kadar air yang terkandung, ini terjadi karena selama ektraksi akan terkena suhu panas, maka semakin lama waktu ekstraksi maka nilai kadar air semakin rendah. Menurut standarisasi agar-agar komersial syarat mutu kadar air maksimal $22 \%$ oleh karena itu agar-agar yang dihasilkan pada penelitian kali ini memenuhi syarat mutu.

\section{Kadar Abu}

Semakin tinggi konsentrasi air kelapa yang ditambahkan maka semakin tinggi pula nilai kadar abu yang dihasilkan. Hal ini dikarenakan kandungan kalium pada air kelapa yang digunakan sebagai pelarut ekstraksi cukup tinggi yaitu $203,70 \mathrm{mg} / 100 \mathrm{~g}$ air kelapa muda sedangkan kandungan kalium pada air kelapa tua yaitu $257,52 \mathrm{mg} / 100 \mathrm{~g}$. adanya kandungan mineral kalium pada air kelapa menyebabkan kation $\mathrm{K}^{+}$bereaksi dengan agar-agar yang menyebabkan nilai kadar abu meningkat. Peningkatan kadar abu disebabkan adanya jumlah kation $\mathrm{K}^{+}$yang terkandung akan bereaksi dengan agar-agar lebih banyak atau sebaliknya (Basmal, 2005).

Semakin lama waktu ekstraksi yang digunakan maka semakin menurun nilai kadar abu. Hal ini dikarenkan kandungan mineral dalam air kelapa. Selain dipengaruhi kandungan mineral pelarut pengekstrak, faktor lingkungan juga mempengaruhi nilai kadar abu. Faktor lingkungan dikaji pada penelitian Alam (2007) yang menyatakan bahwa rumput laut hidup menempel pada karang sehingga pada saat dipanen beberapa karang masih menempel pada bagian rumput laut.

\section{Perlakuan Terbaik}

Perlakuan terbaik dilakukan dengan cara membandingkan setiap parameter dengan standart nilai agar-agar FAO. Parameter yang dibandingan dengan standart agar-agar FAO seperti rendemen, kekuatan gel, viskositas, kadar air, dan kadar abu. Perlakuan terbaik diambil berdasarkan nilai rendemen tertinggi, kekuatan gel tertinggi, viskositas tertinggi, kadar air terendah, dan kadar abu tertinggi. Selain itu yang dijadikan parameter paling penting adalah kekuatan gel tertinggi, karena kekuatan gel sebagai penentu kualitas dalam pembuatan fruit leather. Perbandingan antar parameter hasil perlakuan terbaik dengan standar mutu FAO disajikan pada Tabel 3. 
Tabel 3. Perbandingan Agar-agar Perlakuan Terbaik dengan Agar-agar Standart FAO

\begin{tabular}{|c|c|c|c|}
\hline Spesifikasi & $1: 35$ & waktu ekstraksi 120 menit & FAO \\
\hline Rendemen \% & & 32,27 & Min. 25 \\
\hline Kadar Air \% & & 11,08 & Maks. 22 \\
\hline Kadar Abu \% & & 3,75 & Maks. 6,5 \\
\hline Kekuatan Gel $\left(\mathrm{gr} / \mathrm{cm}^{2}\right)$ & & 235,51 & $200-250$ \\
\hline Viskositas (cP) & & 24,09 & Min. 21 \\
\hline
\end{tabular}

\section{KESIMPULAN}

Penggunaan air kelapa dapat dijadikan sebagai pengganti $\mathrm{NaOH}$ pada proses ekstraksi dalam pembuatan agar-agar dari rumput laut Gracilaria sp . Rasio rumput laut:air kelapa 1:35 dan lama waktu ekstraksi 120 menit mampu menghasilkan agar-agar yang memenuhi syarat standar agar-agar dari FAO yakni nilai rendemen 32,27\%, kadar air 11,08\%, kadar abu 3,75\%, kekuatan gel $235,51 \mathrm{gr} / \mathrm{cm}^{2}$, dan viskositas $24,09 \mathrm{cP}$.

\section{REFERENSI}

Alam, A. 2007. Kualitas Rumput Laut Jenis Euchema spinosum di Perairan Desa Punaga Kabupaten Takalar. Skripsi Fakultas Ilmu Kelautan dan Perikanan, Universitas Hassanudin : Makassar.

Angka, S.L, dan Maggy, T.S. 2000. Bioteknologi Hasil Laut. Bogor: PKSPL-IPB Anggraini, C. 2010. Efek Air Kelapa Terhadap Penarikan Agar pada Proses Pengolahan Rumput Laut (Gracilaria gigas Harv.). Universitas Muhammadiyah Purwokerto: Purwokerto.

Anwar, F. 2003. Pengaruh Kosentrasi KOH yang Berbeda Terhadap Kualitas Alginat Rumput Laut coklat Sargasum Duplikatum. J. G. Agardh Journal of Marine Research. Vol 2, Nomor 1, 7-14.

Basmal. 2005. Pengaruh Konsentrasi Larutan Potasium HIdroksida terhadap Mutu Karaginan Kertas. Jurnal Penelitian Perikanan Indonesia 9 (5):95103.

Castaneda, Y. 2018. Uji Karakter Fisik dan Kimia Karagenan Dari Rumput Laut (E. cottonii) Dengan Variasi Rasio Air Kelapa dan Lama Waktu Ekstraksi Serta Aplikasinya Pada Selai Lembaran Labu Kuning (C. moschata). Skripsi. UMM. Malang

Ega. L., C. G. C. 2016. Artikel Penelitian Kajian Mutu Karaginan Rumput Laut Eucheuma cottonii Berdasarkan Sifat Fisiko-Kimia pada Tingkat Konsentrasi Kalium Hidroksida (KOH) yang Berbeda. Jurnal Aplikasi Teknologi Pangan. 5 (2) : 38-44.

Karyadi, R. 2002. Pengaruh Penambahan Air Kelapa Sebagai Pengganti KOH ( Kalium Hidroksida) pada Proses Penjedalan Dalam Pembuatan Agar-Agar Kertas. Institut Pertanian Bogor: Bogor. 
Moirano, A. L. 1977. Sulfate Seaweed Polysacharides dalam Food Colloids. The AVI Publ.co.Westport Conneticut. Pp 347-381

Muchlisah. 2012. Studi Pengaruh Konsentrasi KOH dan Lama Ekstraksi Terhadap Karakteristik Karaginan Dari Rumput Laut (Euchema cottonii). Universitas Hasanudin: Makassar.

Rahmat. 2002. Pengaruh Penambahan Air Kelapa Sebagai Pengganti KOH pada Pembuatan Agar-Agar Kertas. IPB. Bogor.

Santoso. 2003. Analisis Kandungan Mineral Dalam Air Kelapa Hijau. Universitas Sumatra Utara: Medan. 